\section{To: (Receiving Organization)} Distribution

5. Proj./Prog./Dept./Div.:

Tank 241-T-110/Waste

Management/EP/TWRS Technica

Basis

8. Originator Remarks:

This document is being released into the supporting document system for retrievability purposes.

11. Receiver Remarks: 11A. Design Baseline Document? [] Yes [X] No For release.
3. From: coriginating Organization: Evaluation and Planning

6. Design Authority/ Design Agent/Cog. Engr : :

Dennis J Mccain
4. Related EDT No.:

$\mathrm{N} / \mathrm{A}$

7. Purchase Order No.:

$N / A$
9. Equip./Component No.: $\mathrm{N} / \mathrm{A}$

10. System/B Ldg./Faci $i$ i ty: 241-T-110

12. Major Assm. Dwg. No.:

$$
N / A
$$

13. Permit/Permit Application No.: $\mathrm{N} / \mathrm{A}$

14. Required Response Date: $09 / 18 / 96$

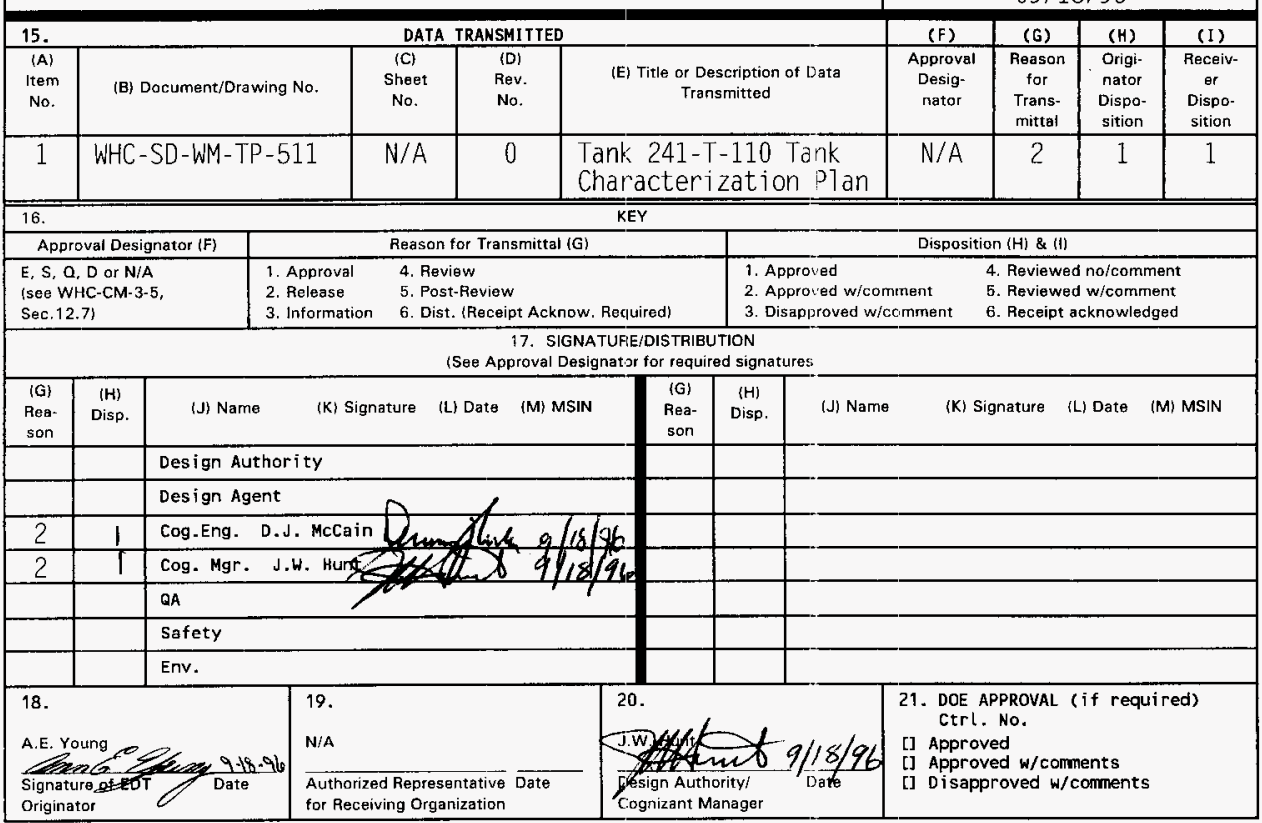




\section{Tank 241-T-110 Tank Characterization Plan}

Dennis J. McCain

Westinghouse Hanford Company, Richland. WA 99352

U.S. Department of Energy Contract DE-AC06-87FiL10930

$\begin{array}{lll}\text { EDT/ECN: } & \text { EDT-617556 } & \text { UC: } 2070 \\ \text { Org Code: } & 79200 & \text { Charge Code: N4G6A } \\ \text { B\&R Code: } & \text { EW 3120074 } & \text { Total Pages: /l }\end{array}$

Key words: Tank 241-T-110. Tank T-110, T-110, T Farm, Tank. Characterization, Plan, TCP

Abstract: $\quad N / A$

TRADEMARK DISCLAIMER. Reference herein to any specific comercial product, process, or service by trade name, trademark, manufacturer, or otherwise, does not necessarily constitute or imply its endorsement, recommendation, or favoring by the United States Government or any agency thereof or $i$ ts contractors or subcontractors.

Printed in the United States of America. To obtain copies of this document, contact: WHC/BCS Document Control Services, P.O. Box 1970, Mailstop H6-08, Richland WA 99352, Phone (509) 372-2420; Fax (509) 376-4989.
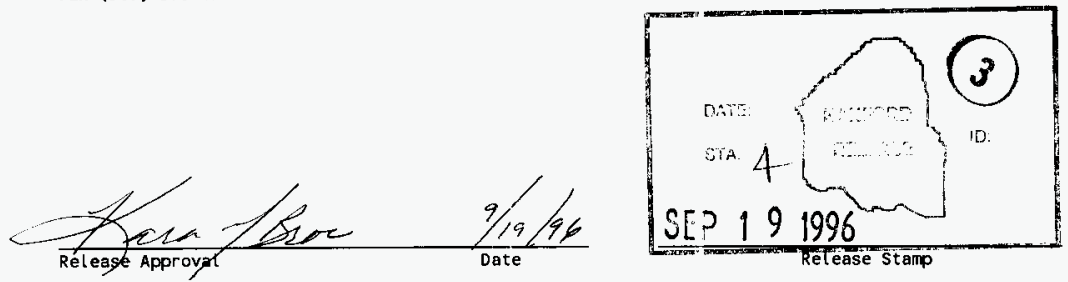

\section{Approved for Public Release}




\title{
TANK 241-T-110 TANK CHARACTERIZATION PLAN
}

\author{
Prepared for the U.S. Department of Energy \\ Office of Environmental Restoration \\ and Waste Management
}


WHC-SD-WM-TP-511, REV 0

TABLE OF CONTENTS

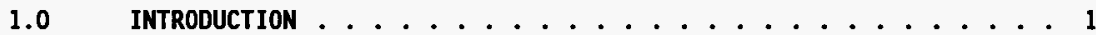

2.0 PROGRAM ELEMENTS REQUIRING INFORMATION FOR TANK 241-T-110 . . . 1

2.1 GENERAL SAFETY ISSUES ................ 1

2.1.1 Safety Screening ............... 1

2.1.2 Vapor Safety Screening ............. 2

2.2 SPECIFIC SAFETY ISSUES .................. . 2

2.2.1 Ferrocyanide .................. 2

2.2.2 Organic Phenomenology ................. 2

2.2.3 Flammable Gas.................... 2

2.2.4 Vapor Space Phenomeriology ............... 3

2.2.5 Criticality .................. 3

2.2.6 High Heat Load .................... 3

2.3 CONTINUING OPERATIONS ................ 3

2.3.1 Compatibility/Stabilization ............. 3

2.3.2 Evaporator ................... 3

2.3.3 Caustic Mitigation ................ 3

2.4 DOUbLE-SHELl TANK WASTE ANALYSIS PLAN ........... 3

2.5 DISPOSAL ................... 3

2.5.1 Retrieval ................. 3

2.5.2 Process Testing .............. 4

2.5.3 Privatization .............. 4

2.6 HISTORICAL MODEL EVALUATION ............... 4

3.0 HOW INFORMATION WILL BE OBTAINED ............. 4

4.0 PRIORITY OF INFORMATION REQUIREMENTS . . . . . . . . . 4

4.1 CHARACTERIZATION BASIS .............. 4

4.2 SAMPLING SCHEDULE ................. 5

5.0 MHEN INFORMATION WILL BE AVAILABLE ...........6 6

6.0 REFERENCES .................... 6

\section{LIST OF TABLES}

4-1 Integrated DQO Requirements and Priorities .........5 


\subsection{INTRODUCTION}

This Tank Characterization Plan (TCP) identifies the information needed to address issues related to short-term and long-term safe storage and long-term management of single she11 tank 241-T-1.10 (T-110). It should be understood that needs and issues surrounding tank T-110 are evolving as new information becomes available. As a result, this TCP addresses only issues that have been identified to date. It is expected that changes may be necessary as additional issues or needs arise which impact the managemert of tank T-110. As necessary, this TCP will be revised to reflect changes. This plan reflects the best information available as of August 1996.

Tank T-110 entered into service in the first quarter of 1945. The tank began receiving second-cycle decontamination waste in the first quarter of 1945 (Agnew et a1. 1995). The tank began to cascade overflow to Tank 241-T-111 in 0ctober 1945. In the second quarter of 1952, the tank began receiving 224 waste in addition to the second-cycle waste. The tank contained second-cycle and 224 waste until the first quarter of 1976. During the third quarter of 1974, the tank received waste water. The tank was removed from service in 1976. A level adjustment was made in April of 1982. The tank was primarily stabilized in 1978 and partially isolated in December 1982. The tank is classified as a sound, non-stabilized tank (Brevick et a1. 1995).

Tank T-110 currently contains a total volume of $1435 \mathrm{~kL}$ ( $379 \mathrm{kgal}$ ) of waste, which is equivalent to $338.5 \mathrm{~cm}(133 \mathrm{in})$ of waste as measured from the baseline of the tank (Hanlon 1996).

Tank T-110 is on the Flammable Gas Watch List.

Near-term sampling and analysis activities are focused on verifying or changing the Watch List tank status, and identifying any new safety issues. If new safety issues are identified, analysis activities consistent with the identified issue will be performed.

In addition to resolving safety issues, it is intended that a11 tank waste will be subject to pretreatment and retrieval to prepare it for final storage or disposal. Presently, these long-range plans are not yet fully identified and, therefore, are not included in this document.

\subsection{PROGRAM ELEMENTS REQUIRING INFORMATION FOR TANK 241-T-110}

This section lists the Tank Waste Remediation System program elements and identifies those that require characterization data from tank T-110.

\subsection{GENERAL SAFETY ISSUES}

\subsubsection{Safety Screening}

The Tank Safety Screening Data Quality Objective (Dukelow et al. 1995) describes the sampling and analytical requirements that are used to screen tank waste for unidentified safety issues. Analytical requirements for tank safety screening are energetics, total alpha activity, moisture content, density and 
WHC-SD-WM-TP-511, REV 0

flammable gas concentration. Based on the these analytical results, additional analysis may be performed.

\subsubsection{Vapor Safety Screening}

All 177 underground tanks must be vapor-sampled for organic solvent screening in accordance with the Recommendation 93-5 Implementation Plan (DOE-RL 1996). Organic solvent screening will be performed using the Scope Increase of "Data Quality Objective to Support Resolution of the Organic Complexant Safety Issue" Rev. 2 (Cash 1996b). The primary vapor analyses conducted will determine Total Non-methane Hydrocarbon content.

Tank T-110 is passively ventilated. Information needs for vapor sampling and analyses of passively ventilated tanks must satisfy Data Quality Objectives for Tank Hazardous Vapor Safety Screening (Osborne and Buckley 1995). The primary analyses employed will determine flammable gas, organic vapor, permanent gas, and moisture content in the tank dome space. Based on these analytical results, additional analysis may be performed.

Tank T-110 was vapor sampled August, 1995 in support of the health and safety vapor Data Quality Objective (DQ0) (Osborne et al. 1995).

\subsection{SPECIFIC SAFETY ISSUES}

\subsubsection{Ferrocyanide}

The ferrocyanide issue is closed. (Cash 1996c).

\subsubsection{Organic Phenomenology}

Tank T-110 is not on the Organic Watch List. It also has not been identified as in scope of the organic DQO by either the Data Quality Objective to Support Resolution of the Organic Complexant Safety Issue (Turner et al. 1995) or the Scope Increase of "Data Quality Objective to Support Resolution of the Organic Complexant Safety Issue" Rev. 2 (Cash 1996b). Therefore, no information needs are currently identified for this program element.

\subsubsection{Flammable Gas}

Tank T-110 has not been identified as in scope of the flammable gas DQO by either the Flammable Gas Safety Program: Data Requirements for Core Sample Analysis Developed through the Data Quality Objectives Process (McDuffie 1995) or the Application of "Flammable Gas Tank Safety Program: Data Requirements For Core Sampling Analysis Developed Through the Data Quality Objectives Process" Rev. 2 (Cash 1996a). Therefore, no flammable gas safety program information needs are currently identified for this tank. 


\subsubsection{Vapor Phenomenology} item.

No information needs from tank T-110 have been identified for this program

\subsubsection{Criticality}

No information other than that for the general safety issue of tank T-110 is currently identified for this program element. However, if the general safety screening of tank T-110 identifies a potential criticality concern, analyses for fissile materials, and neutron sorbers and poisons will be performed as identified in the safety screening DQO (Dukelow et al. 1995).

\subsubsection{High Heat Load}

Tank $\mathrm{T}-110$ is not on the High Heat Watch List; therefore, no information needs are currently identified for this program element.

\subsection{CONTINUING OPERATIONS}

\subsubsection{Compatibility/Stabilization}

Tank T-110 waste will be sampled to determine compatibility. Sampling and analysis requirements will be performed according to the Data Quality objectives for Tank Farms Waste Compatibility Program (Fowler 1995). The analyses employed will be for anions, cations, pH, physical properties, radionuclides, TOC, total uranium, transuranics, and solids content, and moisture content.

\subsubsection{Evaporator}

This section does not apply to tank T-110.

\subsubsection{Caustic Mitigation}

No composition specification is required for tank T-110 (WHC 1996).

\subsection{DOUBLE-SHELL TANK WASTE ANALYSIS PLAN}

This section does not apply because tank $T-110$ is a single-shell tank.

\subsection{DISPOSAL}

\subsubsection{Retrieval}

Current retrieval needs (Bloom and Nguyen 1995) do not call for test samples to be taken from tank T-110. 


\subsubsection{Process Testing}

Tank T-110 has not been identified as a bounding tank for the pretreatment/ disposal process development strategy (Kupfer et al. 1995). Even though tank T110 is not a bounding tank, a portion of archive sample material may be requested for pretreatment testing. The pretreatment strategy does not require any specific analyses to be conducted on the samples.

\subsubsection{Privatization}

This section does not apply because tank $T-110$ has not been chosen to represent a waste envelope as given in the TWRS Privatization Request for Proposal (RFP) (DOE-RL 1996b).

\subsection{HISTORICAL MODEL EVALUATION}

This section does not apply because tank $T-110$ is not identified as a primary or alternate bounding tank for historical model evaluations.

\subsection{HOW INFORMATION WILL BE OBTAINED}

The number of samples required to characterize a tank is a function of waste heterogeneity and the desired confidence to make a correct decision. As directed by the safety screening $0 Q 0$, if inadequate information exists to determine an appropriate number of samples, two vertical profiles will be obtained. These vertical profiles may be obtained using core, auger (for shallow tanks), or grab samples. If analysis of these profiles reveals that additional profiles are necessary to meet data needs, more sample profiles will be requested.

\subsection{PRIORITY OF INFORMATION REQUIREMENTS}

\subsection{Characterization Basis}

The priorities of all the tanks were determined by addressing safety, disposal, and characterization issues in the Tank Waste Characterization Basis (Brown et al. 1996) document. The safety issues with their respective references are: flammable gas (McDuffie 1995, Cash 1996a), organic fuel phenomenology (Turner et al. 1995, Cash 1996b), tank safety screening (Dukelow et al. 1995), vapor screening (DOE-RL 1996, Cash 1996b), vapor space phenomenology (DOE-RL 1996) and ferrocyanide (Meacham et a1. 1995). The disposal issues with their respective references are: privatization (Slankas and Kupfer 1995), process testing (Kupfer et al. 1995), and retrieval (Bloom and Nguyen 1995). The characterization issue with its respective reference is the historical model evaluation (Simpson and McCain 1996). These issues were ranked by priority in the Meeting Minutes of April 26 and 30, 1996 Meetings To Determine TWRS Issue Priorities (TWRS Technical Basis 1996). 


\section{WHC-SD-WM-TP-511, REV 0}

Based on resultant priorities and sampling constraints, tank T-110 is included in the list for sampling and analysis during FY 1996.

\subsection{Sampling Schedule}

Vapor sampling was completed August 1995. Push mode core sampling is scheduled to begin September 1996.

Refer to Table 4-1 for the current DQO requirements and planned sampling and analytical requirements.

Table 4-1: Integrated $D Q Q 0$ Requirements and Priorities

\begin{tabular}{|c|c|c|c|}
\hline Sampling & Appl licable DQOs & $\begin{array}{l}\text { Sampling } \\
\text { Requir rements }\end{array}$ & Analyt loal \\
\hline $\begin{array}{l}\text { Vapor } \\
\text { Sampling }\end{array}$ & $\begin{array}{l}\text {-Organic Solvent } \\
\text { Screening (DOE-RL } \\
1996 \text {, Cash 1996b) } \\
\text {-Heaith and Safety } \\
\text { Vapor DQ0 (Osborne et } \\
\text { al. 1995) }\end{array}$ & $\begin{array}{l}\text { Steel canisters, } \\
\text { Triple Sorbent Traps, } \\
\text { Sorbent Trap Systems }\end{array}$ & $\begin{array}{l}\text { Flammable Gas } \\
\text { Organic Vapors } \\
\text { Permanent Gases }\end{array}$ \\
\hline $\begin{array}{l}\text { Push Mode } \\
\text { Core } \\
\text { Sampling }\end{array}$ & -Safety Screening DQO & $\begin{array}{l}\text { Core samples from } 2 \\
\text { risers separated } \\
\text { radially to the } \\
\text { maximum extent } \\
\text { possible } \\
\text { Combustible gas } \\
\text { measurement }\end{array}$ & $\begin{array}{l}\text { Flammability, } \\
\text { Energetics, } \\
\text { Moisture, Total } \\
\text { alpha activity, } \\
\text { Density }\end{array}$ \\
\hline $\begin{array}{l}\text { Grab } \\
\text { Sampling }\end{array}$ & -Compatibility $\mathrm{DQO}$ & Grab samples & $\begin{array}{l}\text { Energetics, } \\
\text { Moisture, Anions, } \\
\text { Cations, } \\
\text { Radionucl ides, } \\
\text { Specific gravity, } \\
\text { Percent solids, pH, } \\
\text { TOC, TIC, Separable } \\
\text { organics }\end{array}$ \\
\hline
\end{tabular}

* Consult each applicable DQ0 in force at the time for sampling and analytical requirements. 
WHC-SD-WM-TP-511, REV 0

\subsection{WHEN INFORMATION WILL BE AVAILABLE}

According to the Baseline Sampling Schedule (Stanton 1996), data are expected to be available from the push mode core sampling event for tank T-110 in February 1998. This date may be altered if the sampling schedule changes. Data are available from the August 1995 vapor sampling.

\subsection{REFERENCES}

B1oom, G. R. and Q. H. Nguyen, 1995, Characterization Data Needs for Development, Design and Operation of Retrieval Equipment Developed Through the Data Quality Objective Process, WHC-SD-WM-DQO-008, Rev. 0, Westinghouse Hanford Company, Richland, Washington.

Brevick, C. H., L. A. Gaddis, and W. W. Pickett, 1995, Supporting Document for the Northeast Quadrant Historical Tank Content Estimate Report for T Tank Farm, WHC-SD-WM-ER-320, Rev. 0, Westinghouse Hanford Company, Richland, Washington.

Brown, T. M., S. J. Eberlein, J. W. Hurit, and T. J. Kunthara, 1996, Tank Waste Characterization Basis, WHC-SD-WM-TA-164, Rev. 2, Westinghouse Hanford Company, Richland, Washington.

Cash, R. J., 1996a, Application of "Flammable Gas Tank Safety Program: Data Requirements For Core Sampling Analysis Developed Through the Data Quality Objectives Process" Rev. 2 (Internal Memo 79300-96-028, to S. J. Eberlein, July 12), Westinghouse Hanford Company, Richland, Washington.

Cash, R. J., 1996b, Scope Increase of "Data Quality Objective to Support Resolution of the Organic Complexant Safety Issue" Rev. 2 (Internal Memo 79300-96-029, to S. J. Eberlein, Ju7y 12), Westinghouse Hanford Company, Richland, Washington.

Cash, R. J., 1996c, Cancellation of Ferrocyanide DQO Requirements (Internal Memo 79300-96-031, to S. J. Eberlein, July 22), Westinghouse Hanford Company, Richland, Washington.

D0E-RL, 1996a, Recommendation 93-5 Implementation Plan, D0E/RL-94-0001, Rev. 1, U.S. Department of Energy, Richland, Washington.

D0E-RL, 1996b, Request For Proposals (PIFP) No. DE-RP06-96RL13308 [TWRS Privatization], U. S. Department of Energy, Richland, Washington.

Dukelow, G. T., J. W. Hunt, H. Babad, and J. E. Meacham, 1995, Tank Safety Screening Data Quality Objective, WHC-SD-WM-SP-004, Rev. 2, Westinghouse Hanford Company, Richland, Washington. 
Fowler, K. D., 1995, Data Quality Objectives for Tank Farms Waste Compatibility Program, WHC-SD-WM-DQ0-001, Rev. 1, Westinghouse Hanford Company, Richl and, Washington.

Hanlon, B.M., 1996, Waste Tank Summary for Month Ending May 31, 1996, WHC-EP-0182-99, Westinghouse Hanford Company, Richland, Washington.

Kupfer, M. J., W. W. Schultz, and J. T. Slankas, 1995, Strategy for Sampling Hanford Site Tank Wastes for Development of Disposal Technology, WHC-SD-WM-TA-154, Rev. 1, Westinghouse Hanford Company, Richland, Washington.

McDuffie, N. G., 1995, Flammable Gas Tänk Safety Program: Data Requirements for Core Sample Analysis Developed Through the Data Quality Objectives Process, WHC-SD-WM-DQ0-004, Rev. 2, Westinghouse Hanford Company, Richland, Washington.

Meacham, J. E., 1995, Data Requirements for the Ferrocyanide Safety Issue Developed Through the Data Quality Objectives Process, WHC-SD-WM-DQ0-007, Rev. 2, Westinghouse Hanford Company, Richland, Washington.

Osborne, J. W., and L. L. Buckley, 1995, Data Quality Objectives for Tank Hazardous Vapor Safety Screening, WHC-SD-WM-DQ0-002, Rev. 2, Westinghouse Hanford Company, Richland, Washington.

Osborne, J. W., J. L. Huckaby, and E. F. Hewitt, 1995, Data Quality Objectives for Generic In-Tank Health and Safety Vapor Issues Resolution, WHC-SD-WMDQ0-002, Rev. 1, Westinghouse Hanford Company, Richland, Washington.

Simpson, B. C., and D. J. McCain, 1996, Historical Model Evaluation Data Requirements, WHC-SD-WM-DQ0-018, Rev. 1, Westinghouse Hanford Company, Richland, Washington.

Slankas, J. T., M. J. Kupfer, 1995 Data Needs and Attendant Data Quality Objectives for Tank Waste Pretreatment and Disposal, WHC-SD-WM-DQ0-022, Rev. 0, Westinghouse Hanford Company, Richland, Washington.

Turner, D. A., H. Babad, L. L. Buckley and J. E. Meacham, 1995, Data Quality Objective to Support Resolution of the Organic Complexant Safety Issue, WHC-SD-WM-DQ0-006, Rev. 2, Westinghouse Hanford Company, Richland, Washington.

TWRS Technical Basis, 1996, Meeting Minutes of April 26 and 30, 1996 Meetings To Determine TWRS Issue Priorities, (Internal Memo 79000-96-001 to R. F. Bacon, May 20), Westinghouse Hanford Company, Richland, Washington.

Von Bargen, B. H., 1995, 242-A Evaporator/Liquid Effluent Retention Facility Data Quality objectives, WHC-SD-WM-DQO-014, Rev. 1, Westinghouse Hanford Company, Richland, Washington. 


\section{WHC-SD-WM-TP-511, REV 0}

WHC, 1996, Operating Specifications For Single-Shell Waste Storage Tanks, Rev. D-12, 0SD-T-151-00013, Westinghouse Hanford Company, Richland, Washington. 